\title{
Chemical Pond Water Contamination-icpms Investigations in the Various Areas of Eluru City, Andhra Pradesh, India-a Case Study.
}

BOGGU JAGAN MOHAN REDDY ( $\sim$ drbjaganreddy@gmail.com )

Adikavi Nannaya University

\section{Ganteda Rama Rao}

NGRI: National Geophysical Research Institute CSIR

K. V. B. Ranjitha

Adikavi Nannaya University

G. Satya Sree

Adikavi Nannaya University

Naresh Kumar Katari

GITAM Institute of Science

\section{Research Article}

Keywords: Water contamination, Anthropogenic activity, Pathogenic organisms, Total Dissolved solids (TDS), Electrical Conductivity (EC), Chloride Content (CC), pH and Total Hardness (TH)

Posted Date: December 28th, 2021

DOI: https://doi.org/10.21203/rs.3.rs-1179828/v1

License: (c) (i) This work is licensed under a Creative Commons Attribution 4.0 International License. Read Full License 


\section{Abstract}

The several stagnant water resources contamination in urban areas mainly caused by anthropogenic activities and as well as pathogenic organisms. The objective of the present study is to determine the chemical contamination in pond water regardingsudden appearance of health problems among the people of certain areas in Eluru, West Godavari District, Andhra Pradesh, India. The results of ICP-MS investigations showed elemental impurities in water samples and physio-chemical parameters of pond water such as pH, TDS, EC, CC , Total Hardness etc., are studied in detailed.

\section{Introduction}

The pond water is natural resource which is rigid by limited area [1].The volume of ground water in storage exceeds then they deposited rest volume of fresh surface water in the form of ponds, lakes, streams, and rivers etc., [2][4]. This water which occurs in fully saturated soils and geological formations [4][5].Many animals that live in surrounding area, migrating birds spent their incubation period nearby plants depend on these ponds for a rich source of nutrients and water [3].

Pond water contamination mainly caused by two ways one is anthropogenic activities such as waste disposal including manufacturing and service industries, agriculture activities like pesticides and fertilizers utility, irrigation, domestic waste production by bathing, drinking and washing for humans and other animals etc.,[ 6] Second one is Pathogenic organisms such as facial coliforms, streptococci, Salmonella, algae and fungi etc., occurrence in water may increase the risks of water related diseases and health problems in local residents [6][7][9]. Remedial actions to clean up aquifers are difficult, expensive, and sometimes it's not possible. Many laws and regulations are controlling the water contamination. According to WHO (World Health Organization) [10] [11] water quality will be recommended that the acceptable limits of contaminants in water. Plenty of nations implemented contaminants acceptable levels in water based on the availability of resources in their geographical circumference as follows

1. India follows - Bureau of Indian Standards (BIS)

2. United States follows- The united states Environmental Protection Agency Standards (USEPA standard)

3. European Union follows - the quality of water intended for human consumption (80/778/EEC) and Council Directive 98/83/EC (EU Derectives).

\section{Sample Collection}

The Eluru is well connected by road and rail with rest of the country. The city is having only few industries and small-scale industries such as the Incense sticks industry, small-scale chemical industries, hair processing industries, automobile workshops, aquaculture-related labs, water plants etc. The people are mostly in-service sector. 
The sudden appearance of some health problems among people of certain areas in Eluru, West Godavari District, Andhra Pradesh in December 2020, was taken up by a multi-disciplinary team of experts from Adikavi Nannaya University.

The expert team from the University has visited the affected areas on 11th and 12 December 2020 to conduct survey and to collect water samples in Eluru City. The information was collected from the sufferers through questionnaire with the help of teachers and student volunteers of National Service Scheme wings of Adikavi Nannaya University affiliated colleges. The survey data related to symptoms, food and water intake, life style, medical history etc. was analysed. The sufficient quantity of water samples was collected from various sources in the city which are listed and labelled as follows

- A-Pre-filtered Godavari water at Pampula Cheruvu

- B- Filtered Godavari water at Pampula Cheruvu

- C-Municipal water at Arundhatipeta

- D- Bore well water at TurupuVeedhi

- E-Bore well water at DakshinapuVeedhi

- F-Godavari water at Denduluru summer storage tank

- G-Tammileru downstream water

- $\mathrm{H}$ - Tammileru water at Ashoknagar Bridge

- I-Krishna canal water at Padamatilakulu before joining Tammileru

- J-Bore well water at Hanuman peta

To analyse the basic water quality parameters the same samples were sent to Laboratory for further analyses.

Waste disposal in water resources by anthropogenic activities solid content dissolved in water due to this the aquatic nature of water resources has been changed [12]. The contaminated water samples may exhibit inorganic ions, such as chlorides, nitrates, heavy metals and complex synthetic organic chemicals etc., [13] [16]. TDS method is useful to measure the dissolved combined contents of all inorganic and organic substances present in water. Typically, TDS concentrations are reported in parts per million (ppm) [14]. This test does not provide the specific water quality that is Elevated Hardness such as mineral content in water, Salty /Taste or Corrosiveness called as aggressive water which is how water dissolves with other materials. Therefore, the TDS test is used as an indicator test to determine the general quality of the water only. The water with high TDS value indicates that water is highly mineralized. Desirable limit for TDS is $500 \mathrm{mg} / \mathrm{L}$ and maximum limit is $1000 \mathrm{mg} / \mathrm{L}$ which is prescribed for drinking purposes [31]. By examination of the above said water samples Total Dissolved Solids (TDS) are listed below (Figure2) as follows 
Based on the above said data the concentration of Total Dissolved Solids in various water samples at Eluru city are found to be within the limit of WHO standards except bore well water at Hanuman peta. It seems to be minor concentration of solids in bore well water at Hanuman peta exceeds the desired limits of WHO.

Due to the occurrence of solids in water samples may analyse for metals. In case of heavy metals in the water samples it may cause toxic nature in human health. Because metals are more soluble in water [15]. Heavy metal toxicity can result in damaged or reduced mental and central nervous function, lower energy levels, and damage to blood composition, lungs, kidneys, liver, and other vital organs[17].By examination of the above said water samples for availability of metals listed below (Figure3) as follows

Figure 3: water samples for availability of metals

Based on World Health Organization (WHO) the acceptable concentrations of cited above metals are found to be as follows 
Table 1

acceptable concentrations

\begin{tabular}{|c|c|c|c|}
\hline $\begin{array}{l}\text { S. } \\
\text { No. }\end{array}$ & $\begin{array}{l}\text { Name of } \\
\text { the Element }\end{array}$ & $\begin{array}{l}\text { Acceptable Limit in } \\
\text { drinking water }\end{array}$ & Reference \\
\hline 1 & $\begin{array}{l}\text { Chromium } \\
\text { (Cr) }\end{array}$ & $0.05 \mathrm{mg} / \mathrm{L}$ or $50 \mu \mathrm{g} / \mathrm{L}$ & Chromium in drinking-water- WHO (2003) \\
\hline \multirow[t]{2}{*}{2} & \multirow{2}{*}{$\begin{array}{l}\text { Manganese } \\
(\mathrm{Mn})\end{array}$} & \multirow{2}{*}{$\begin{array}{l}\text { Not of health concern } \\
\text { at levels found in } \\
\text { drinking-water }\end{array}$} & IPCS (1999) Manganese and its compounds \& \\
\hline & & & Manganese in drinking-water- WHO (2011) \\
\hline 3 & Iron (Fe) & $\begin{array}{l}\text { Not of health concern } \\
\text { at levels found in } \\
\text { drinking-water }\end{array}$ & Iron in drinking-water- WHO (2003) \\
\hline 4 & Cobalt (Co) & - & - \\
\hline \multirow[t]{2}{*}{5} & Nickel (Ni) & $0.07 \mathrm{mg} / \mathrm{L}$ or $70 \mu \mathrm{g} / \mathrm{L}$ & Nickel in drinking-water- \\
\hline & & & WHO (2005) \\
\hline 6 & $\begin{array}{l}\text { Copper } \\
\text { (Cu) }\end{array}$ & $2 \mathrm{mg} / \mathrm{L}$ or $2000 \mu \mathrm{g} / \mathrm{L}$ & $\begin{array}{l}\text { IPCS (1998) Copper \& Copper in drinking-water- } \\
\text { WHO (2003) }\end{array}$ \\
\hline 7 & Zinc (Zn) & $\begin{array}{l}\text { Not of health concern } \\
\text { at levels found in } \\
\text { drinking-water }\end{array}$ & Zinc in drinking-water- WHO (2003) \\
\hline 8 & $\begin{array}{l}\text { Cadmium } \\
(\mathrm{Cd})\end{array}$ & $0.003 \mathrm{mg} / \mathrm{L}$ or $3 \mu \mathrm{g} / \mathrm{L}$ & $\begin{array}{l}\text { FAO/WHO (2011) Evaluation of certain food } \\
\text { additives and contaminants \& Cadmium in drinking- } \\
\text { water- WHO (2011) }\end{array}$ \\
\hline 9 & $\begin{array}{l}\text { Mercury } \\
(\mathrm{Hg})\end{array}$ & $0.006 \mathrm{mg} / \mathrm{L}$ or $6 \mu \mathrm{g} / \mathrm{L}$ & $\begin{array}{l}\text { IPCS (2003) Elemental mercury and inorganic } \\
\text { mercury compounds \& Mercury in drinking-water- } \\
\text { WHO (2005) }\end{array}$ \\
\hline 10 & Lead $(\mathrm{Pb})$ & $0.01 \mathrm{mg} / \mathrm{L}$ or $10 \mu \mathrm{g} / \mathrm{L}$ & $\begin{array}{l}\text { FAO/WHO (2011) Evaluation of certain food } \\
\text { additives and contaminants \& Lead in drinking- } \\
\text { water-WHO (2011) }\end{array}$ \\
\hline
\end{tabular}

By examination of the experimental values of cited above metals and reference values looks like within the limits of WHO standards only. With respect to water one parts per million that is 1PPM is equal to approximately one milligram per litre that is $1 \mathrm{mg} / \mathrm{L}$.

The contamination of water by these foreign materials decreases the quality of the water. To identify the quality of the water sample $\mathrm{pH}$ indicator is more useful method to determine the water sample is either acidic or basic in nature. $\mathrm{pH}$ is denoting as potential of hydrogen or powder of hydrogen [18]. The $\mathrm{pH}$ of water is a very important measurement concerning water quality. The range is going from 0 to $14 . \mathrm{pH} 7$ is indicated as neutral. $\mathrm{pH}$ of less than 7 indicate acidity, whereas a $\mathrm{pH}$ of greater than 7 indicates a base [19]. A changing of $\mathrm{pH}$ in a Pond/ stream/ lake or a river can be an indicator of increasing pollution or some other environmental factor. $\mathrm{pH}$ is really a measure of the relative amount of free hydrogen and 
hydroxyl ions in the water. Water that has more free hydrogen ions is acidic, whereas water that has more free hydroxyl ions is basic [21]. $\mathrm{H}$ can be affected by chemicals in the water, due to this $\mathrm{pH}$ is an important indicator of water. WHO has recommended maximum permissible limit of $\mathrm{pH}$ for drinking water is 6.5 to $8.5[31$ ]. By examination of the above said water samples for $\mathrm{pH}$ is listed below (Figure4) as follows

Based on the above said data the Hydrogen potential $(\mathrm{pH})$ in various water samples at Eluru city are found to be within the limit of WHO standards. Out of which Godavari water at Denduluru summer storage tank and Krishna canal water at Padamatilakulu before joining Tammileru are seems to be slightly basic in nature.

Hardness of water is caused by compounds of calcium, magnesium and by a variety of other metals [22] [23]. Water systems using groundwater as a source are concerned with water hardness, since as water moves through soil and rock it dissolves small amounts of naturally-occurring minerals and polyvalent metallic ions [26]. General guidelines for classification of waters are: 0 to $60 \mathrm{mg} / \mathrm{L}$ (milligrams per litter) as calcium carbonate is classified as soft; 61 to $120 \mathrm{mg} / \mathrm{L}$ as moderately hard; 121 to $180 \mathrm{mg} / \mathrm{L}$ as hard; and more than $180 \mathrm{mg} / \mathrm{L}$ as very hard [24]. Hard water has some benefits to humans, animals and other living organisms. Humans need minerals to stay healthy, and the World Health Organization (WHO) states that drinking-water may be a contributor of calcium and magnesium in the diet and could be important for those who are marginal for calcium and magnesium intake [25]. Hence, the water exceeds the limits of hardness it may spoils the functioning of human organs and it leads to die. According to WHO standards, the permissible range of Calcium should be $100-300 \mathrm{mg} / \mathrm{L}$ whereas magnesium is 50 $\mathrm{mg} / \mathrm{L}$ probably lower than calcium. In some cases, consumers tolerate water hardness more than $500 \mathrm{mg} / \mathrm{L}$ also [31]. By examination of the above said water samples from various areas the Total Hardness is listed below (Figure5) as follows

Based on the above said data the concentration of Total Hardness $(\mathrm{TH})$ in various water samples at Eluru city are exhibits within the limit of WHO standards only.

Typically, the quantity of dissolved solids in water determines the electrical conductivity. Electrical Conductivity (EC) could measures the ionic process of a solution and it allows to transmit current. Pure water is not a good conductor of electric current. It's a good insulator. Ifionic contraction will be increased it will enhance the electrical conductivity of water. According to WHO standards, EC value should not exceeded $400 \mu \mathrm{S} / \mathrm{cm}$.

Disinfection is one of the most important and unquestionable factors for safe drinking water. The destruction of Pathogenic microorganisms (typically bacterial, viral, protozoan or other bio-logical) chlorine is commonly used as reactive chemical agent [27] [28] [29]. High levels of turbidity of infection diminish the growth of bacteria by chlorine. But higher levels of chlorine concentration give a salty taste to water [30]. Taste thresholds for the chloride anion depend on the associated cations are in the range of 200-300 mg/l for sodium, potassium and calcium chloride. No health-based guideline value is proposed 
for chloride in drinking-water [31]. By examination of the above said water samples from various areas the chlorine concentration is listed below (Figure5) as follows:

In the above said various study areas, the chloride content is within the limits of threshold point only.

\section{Declarations}

\section{Acknowledgements:}

Authors sincerely thanks to

1. Creative common Attribution-Road map of Eluru, Andhra Pradesh; 3 May 2019, 16:42:26-Creative CommonsAttribution-Share Alike 4.0 International license.

2. Suven Pharmaceuticals Itd., Jeedimetla, Hyderabad, 500055

3. Sir CR Reddy Autonomous College, Eluru, Andhra Pradesh, 534007

4. the Director of the National Geophysical Research Institute, Hyderabad,

5. Vice Chancellor of AdikaviNannaya University, Rajamahendravaramfor his encouragement, and permission to publish this paper.

\section{References}

1. STANLEY, E. G. (1 June 1975). "THE MERRIAM-WEBSTER DICTIONARY THE OXFORD ILLUSTRATED DICTIONARY". Notes and Queries. 22 (6): 242-243. doi:10.1093/nq/22-6-242. ISSN 1471-6941.

2. F. P. Brooks, Jr., in Proceedings of the 1977 International Federation of Information Processing, B. Gilchrist, Ed. (North-Holland, Amsterdam, 1977), p. 625

3. "Freshwater ecosystems". Forest Research. 29 May 2018. Retrieved 16 November 2020.

4. R. Diamond, in Computational Crystallography, D. Sayre, Ed. (Oxford Univ. Press, Oxford, 1982), p. 318; T. A. Jones, in ibid., p. 303.

5. F. P. Brooks, Jr., in Proceedings of the 1977 International Federation of Information Processing, B. Gilchrist, Ed. (North-Holland, Amsterdam, 1977), p. 625

6. Klecka, G., Persoon, C. and Currie, R. (2010) Chemicals of Emerging Concern in the Great Lakes Basin: An Analysis of Environmental Exposures. Reviews of Environmental Contamination and Toxicology, 207, 1-93. http://dx.doi.org/10.1007/978-1-4419-6406-9_1.

7. Ashbolt, N.J. (2004) Microbial Contamination of Drinking Water and Disease Outcomes in Developing Regions. Toxicology, 198, 229

8. Zoller, U. (2004) Handbook of Detergents: Part B Environmental Impact. Marcel Dekker, New York, 838.

9. Suthar, S., Chhimpa, V. and Singh, S. (2009) Bacterial Contamination in Drinking Water: A Case Study in Rural Areas of Northern Rajasthan, India. Environmental Monitoring and Assessment, 159, 43-50. 
http://dx.doi.org/10.1007/s10661-008-0611-0

10. Manual on Water Supply and Treatment, third edition - revised and updated May 1999, Ministry of Urban Development, New Delhi.

11. WHO Guidelines for Drinking Water Quality. 3rd Edition Vol. 1 Recommendations, 2008.

12. Dixit, S., Yadav, A., Dwivedi, P. D., \& Das, M. (2014). Toxic hazards of leather industry an technologies to combat threat: a review. Journal of Cleaner Production, 39-39

13. Klecka, G., Persoon, C. and Currie, R. (2010) Chemicals of Emerging Concern in the Great Lakes Basin: An Analysis of Environmental Exposures. Reviews of Environmental Contamination and Toxicology, 207, 1-93. http://dx.doi.org/10.1007/978-1-4419-6406-9_1

14. "Salinity and drinking water :: SA Health". www.sahealth.sa.gov.au. Retrieved 2020-02-22.

15. "What Is The Acceptable Total Dissolved Solids (TDS) Level In Drinking Water?". The Berkey. Retrieved 2020-02-22.

16. Voutsaand D, Samara C, 2002.Labile and bio accessible fractions of heavy metals in the airborne particulate matter from urban and industrial areas. Atmospheric Environment, 3583-3590.

17. Heavy metal water pollution- A case study, Rashmi Verma1 and Pratima Dwivedi2 1Dept of Chemistry Dr C.V. Raman University Kota Bilaspur, India. 2Dept of Chemistry ChoukseyEngg college Bilaspur, India.Recent Research in Science and Technology 2013, 5(5): $98-99$ ISSN: 2076-5061 Available Online: http://recent-science.com

18. Jensen, William B. (2004). "The Symbol for pH"(PDF). Journal of Chemical Education. 81 (1): 21. Bibcode:2004JChEd..81...21J. doi:10.1021/ed081p21

19. Lim, Kieran F. (2006). "Negative pH Does Exist". Journal of Chemical Education. 83 (10): 1465. Bibcode:2006JChEd..83.1465L. doi:10.1021/ed083p1465

20. Nørby, Jens (2000). "The origin and the meaning of the little $p$ in $p H "$. Trends in Biochemical Sciences. 25 (1): 36-37. doi:10.1016/S0968-0004(99)01517-0. PMID 10637613

21. IUPAC, Compendium of Chemical Terminology, 2nd ed. (the "Gold Book") (1997). Online corrected version: (2006-) "activity (relative activity), a". doi:10.1351/goldbook. A00115

22. "Hard water". National Groundwater Association. Retrieved 28 June 2019

23. Christian Nitsch, Hans-Joachim Heitland, Horst Marsen, Hans-Joachim Schlüussler, "Cleansing Agents" in Ullmann's Encyclopedia of Industrial Chemistry 2005, Wiley-VCH, Weinheim. doi:10.1002/14356007.a07_137

24. World Health Organization Hardness in Drinking-Water, 2003

25. "Drinking Water Hardwater Hardness Calcium Magnesium Scale Stained Laundry". Waterresearch.net. Retrieved 2013-01-26.

26. Ground water contamination in the United States VI Pye and R Patrick; Science 221 (4612), 713-718. DOI: 10.1126/science.6879171. http://science.sciencemag.org/content /221/4612/713 ; http://www.sciencemag.org/help/reprints-and-permissions. 
27. Scott, James (trans.). On the disinfecting properties of Labarraque's preparations of chlorineArchived 2015-12-31 at the Wayback Machine (S. Highley, 1828) Accessed Nov 1, 2011.

28. Greenwood 1997, p. 860.

29. Wiberg 2001, p. 411.

30. Hammond, C. R. (2000). The Elements, in Handbook of Chemistry and Physics (81st ed.). CRC press. ISBN 978-0-8493-0481-1.

31. WHO (2011) Guidelines for drinking-water quality, 4th edn. Geneva, Switzerland

\section{Figures}

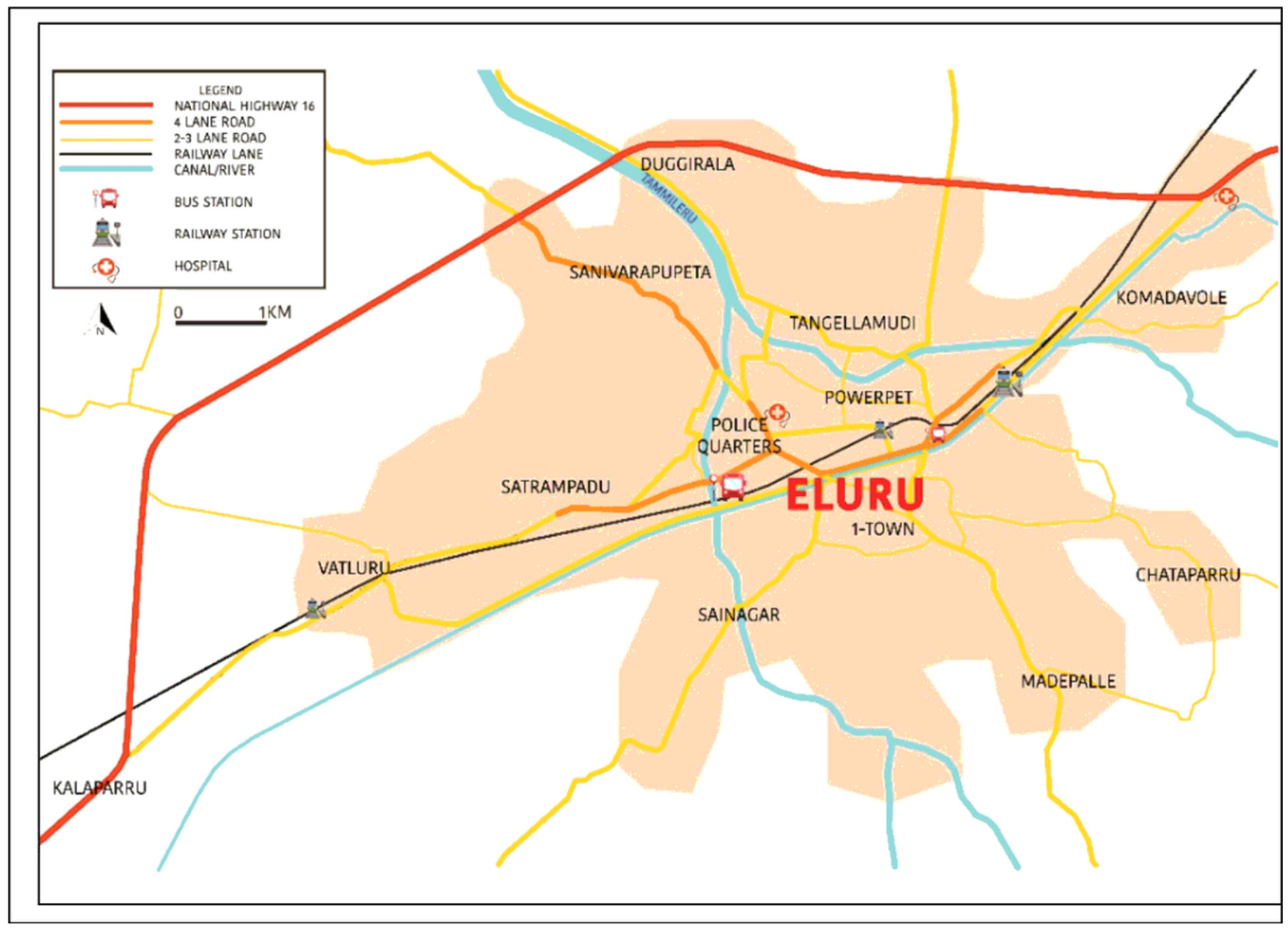

Figure 1

Road map of Eluru City 


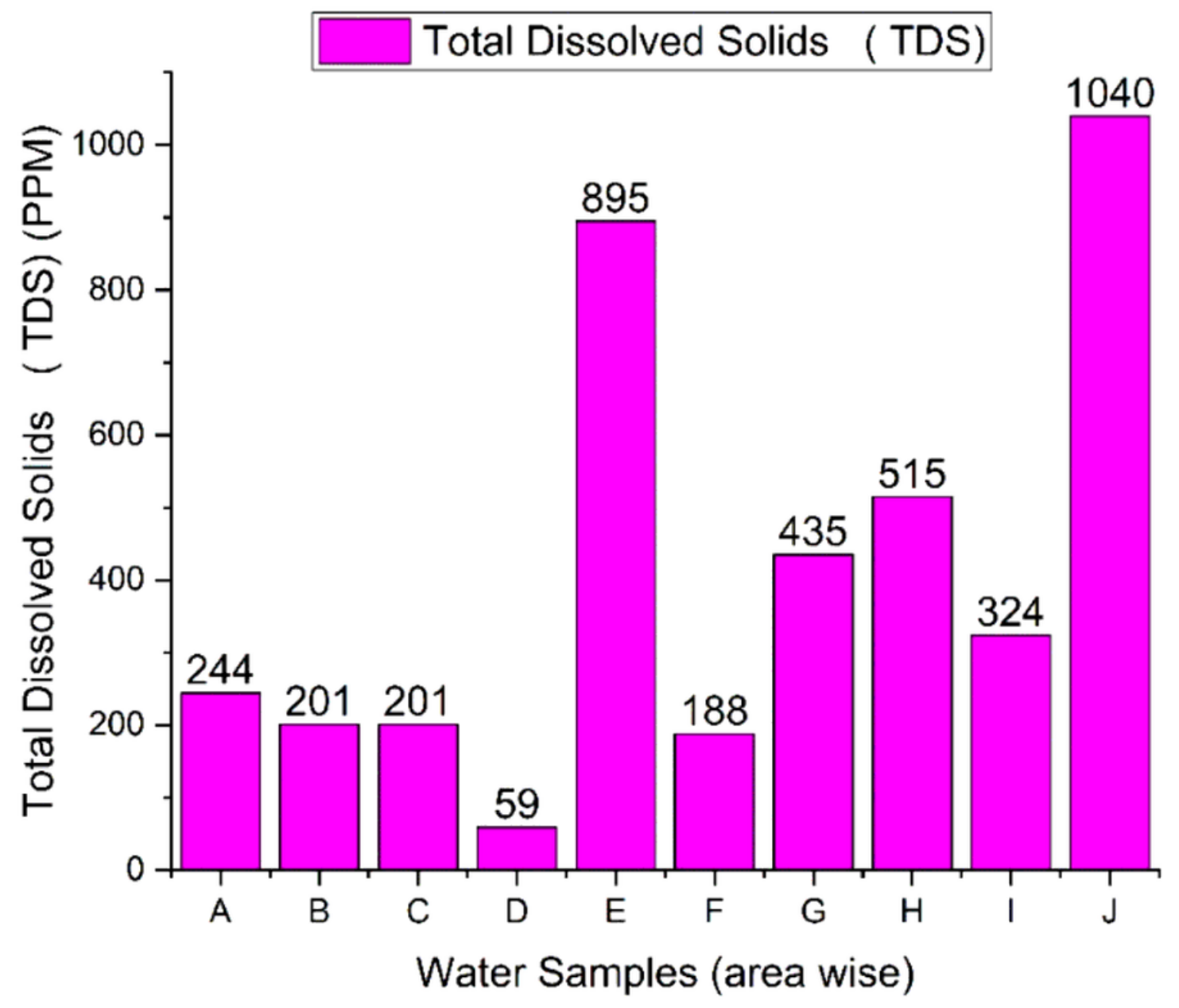

Figure 2

Total Dissolved Solids(TDS) 


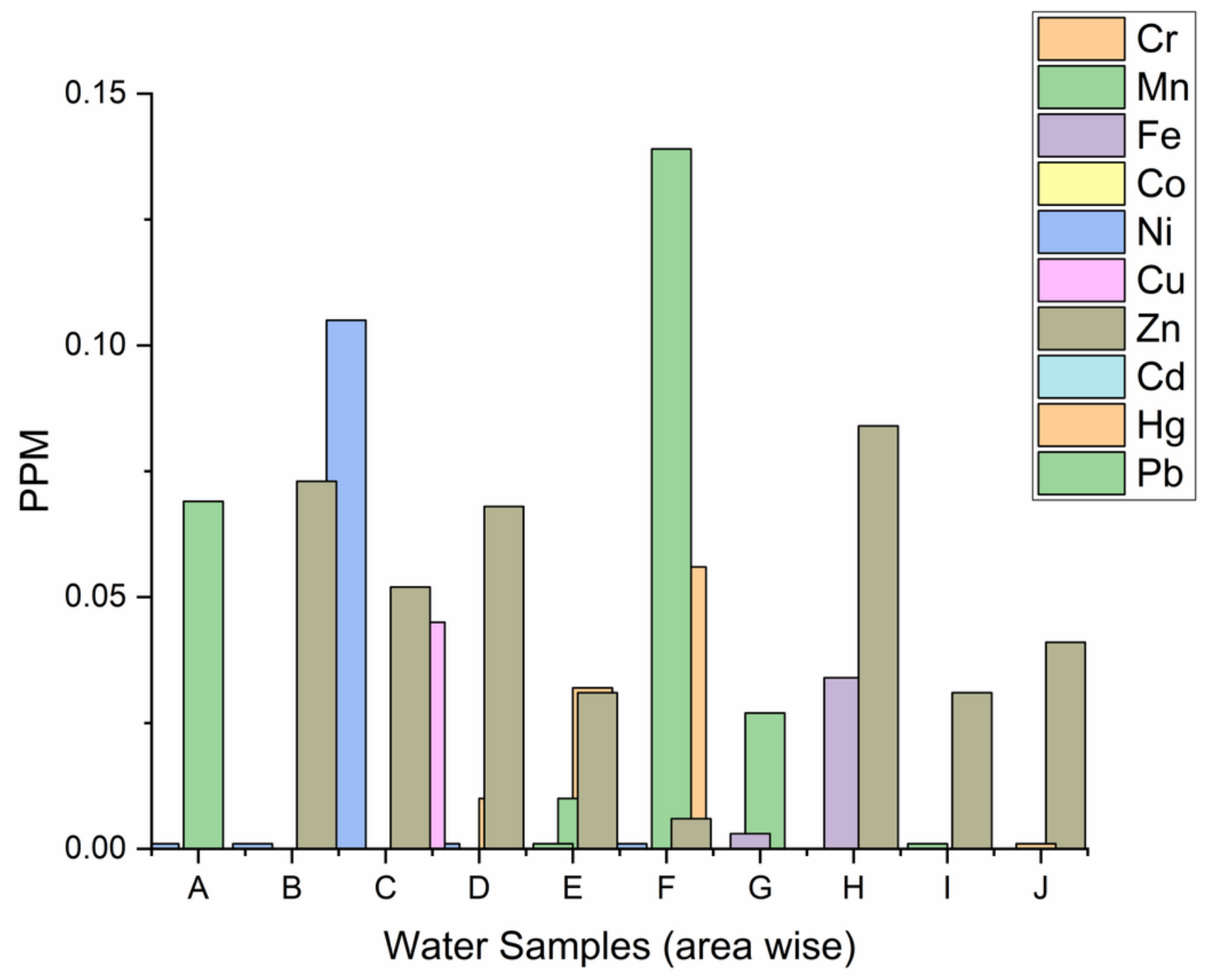

Figure 3

water samples for availability of metals 


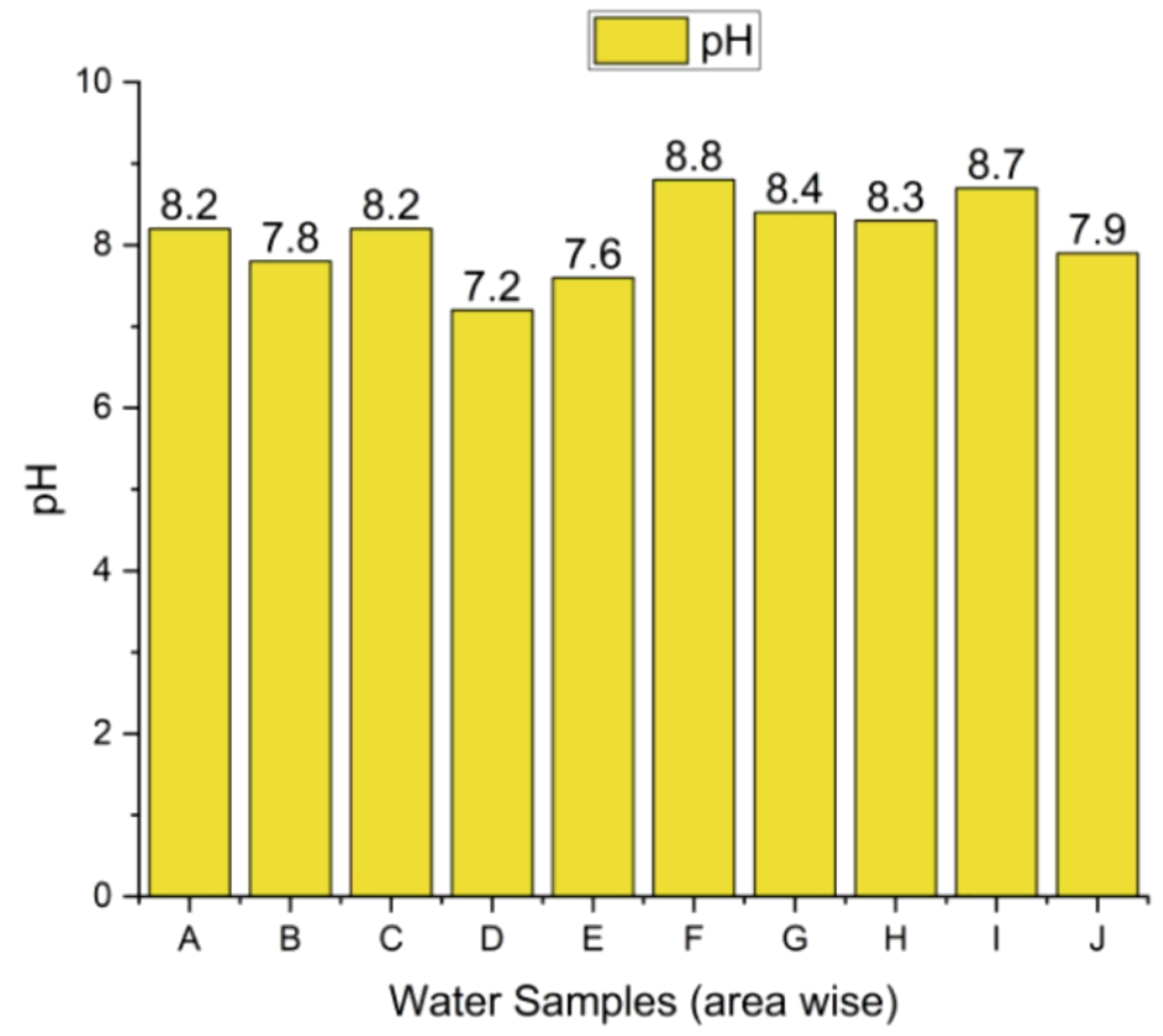

Figure 4

water samples for $\mathrm{pH}$ 


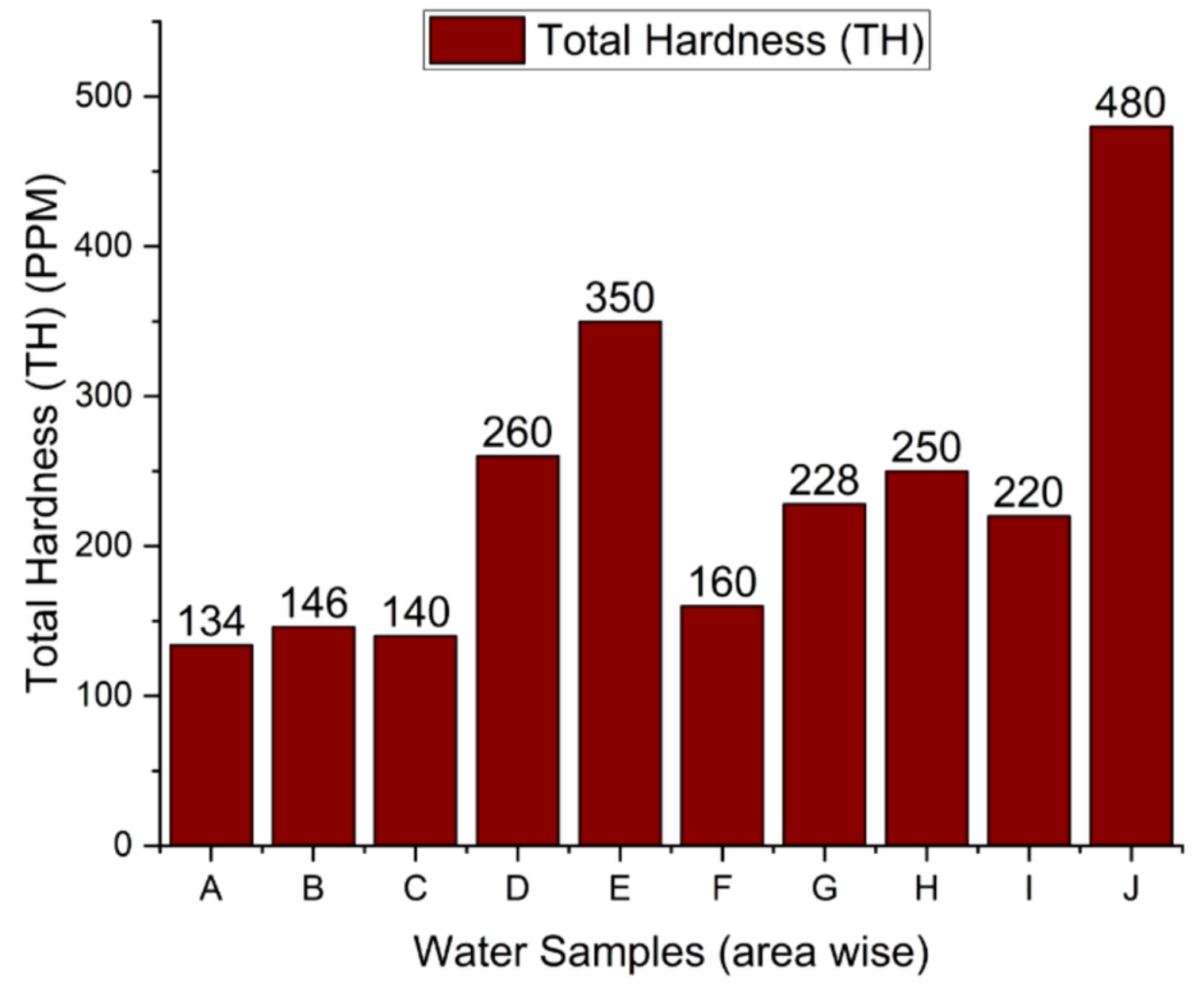

Figure 5

Total Hardness 


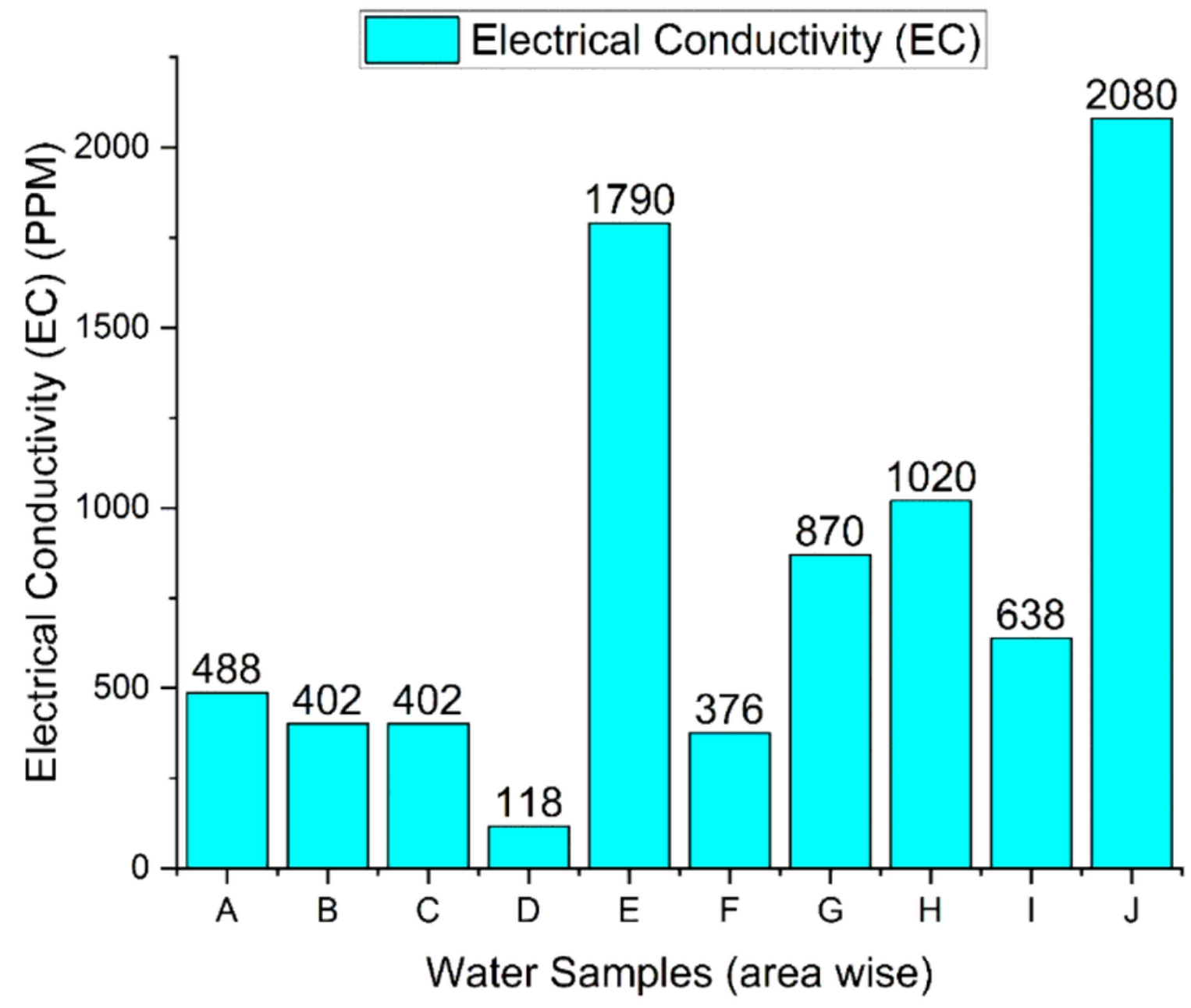

Figure 6

Electrical conductivity (EC) 


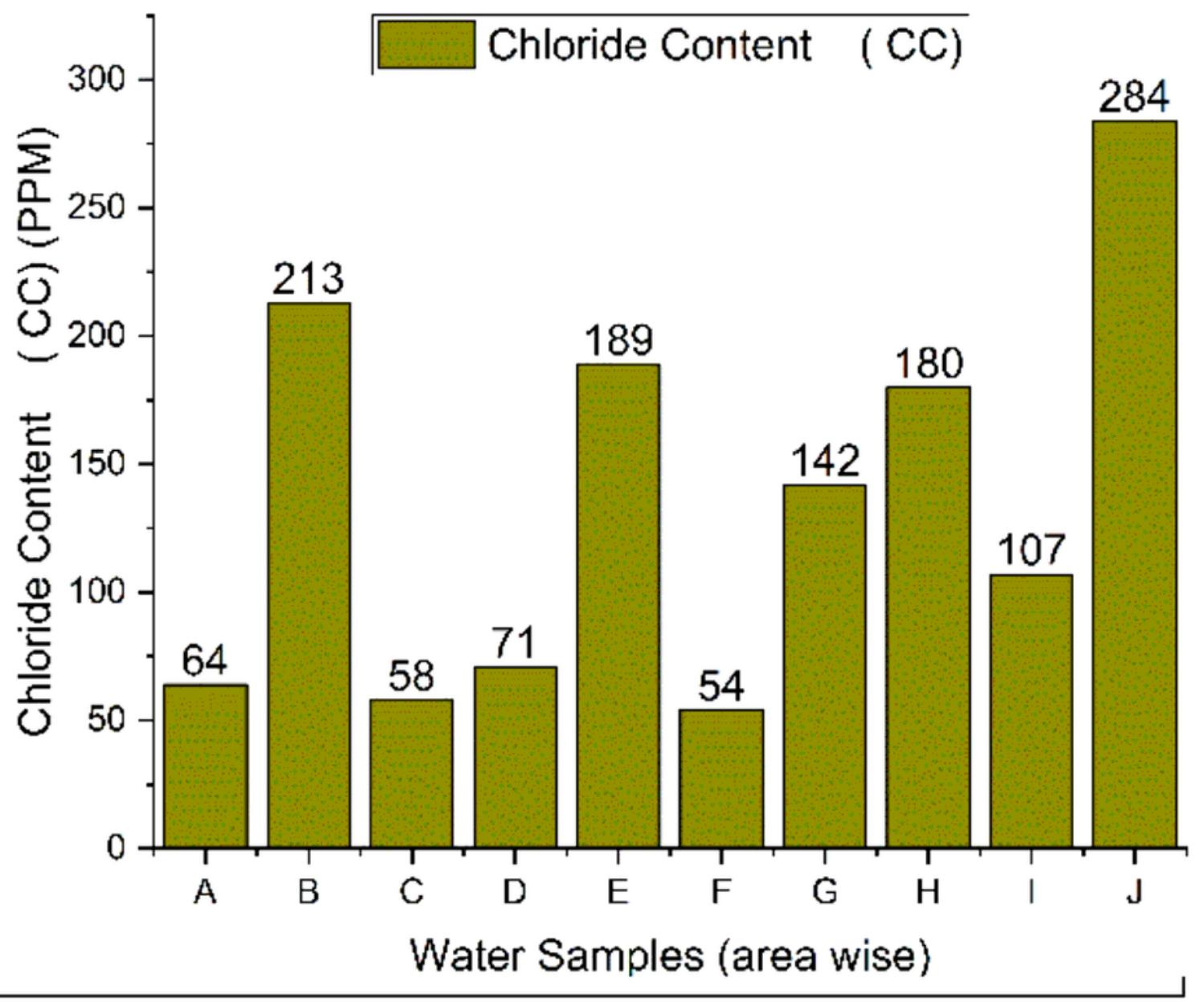

Figure 7

Chloride content 